\title{
The Foundations of Acquisition Policy in the Small University Library
}

\author{
Mr. Grieder is librarian, West Virginia \\ University.
}

W

HAT APPEARS to be a recent tendency to think of university library problems in terms of the great research collections has somewhat obscured the fact that certain questions and dilemmas sometimes take on a different aspect and emphasis in small libraries. While the large universities in the aggregate may have more students and more books than the smaller ones, the latter nevertheless represent a good share of public and private education enterprise, and their library problems deserve consideration. In this connection the American Library Directory, 1948, indicates that onehalf the state universities of the country possess fewer than 300,000 volumes, and that these institutions for the most part are in areas having no large private foundations with good libraries. The universities of New Hampshire, Maine, Georgia, Mississippi, Oklahoma and the mountain statesexcept for Colorado-may be cited as examples.

The matter of size is not necessarily an index to the degree of adequacy with which their collections meet the needs of these institutions, until the aims and programs of each school and the contents of each library are duly considered. However, there are good reasons for supposing that many people, including the administrators of most of them, regard these libraries as inadequate, and are working diligently to increase book funds and to extend the re- sources of their collections by other means - gifts, cooperative enterprises and the like. For student bodies of approximately equal size, demanding and needing books and services for similar work, the small libraries could not offer the same degree of adequacy as the larger ones.

Everyone knows how greatly enrolments in almost all schools have expanded since the war. In 1939-40 seven state universities with below-median libraries-Florida, Georgia, Maryland, Oklahoma, Tennessee, Utah and West Virginia-had enrolments ranging from 3245 to 6935 students; in 1946-47 the range was from 6org to $9846 .^{1}$ This increase is still more impressive when it is noted that the universities of Colorado, Indiana, Iowa, Missouri, Nebraska, North Carolina, Oregon and Virginia all had fewer than 7000 students in $1939-40$, and that four had less than 4000 . It appears that in size the first named universities are now comparable to the latter as they existed in $1939-40$, and that they have in some cases far exceeded them.

Whether they are subject to the same library demands is another question. Examination of catalogs indicates that they are not as yet offering equivalent curricula, though new programs are being added, and probably the greater variety of interests accompanying a larger enrolment and the crowded condition of almost all outside universities have created considerable pressure

${ }^{1}$ U.S. Office of Education. College and University Library Statistics, 1939-40. Washington, Government Printing Office, 1943; Library Statistics of Colleges and Universities with Enrollments of 5,00o students or more, 1946-47. (Circular No. 243, June 1948.) 
for more professional and research offerings in every university with a closely restricted program. It is entirely reasonable to suppose that these demands will continue to be voiced, and will perhaps become more pressing, particularly if the currently favorable market for teachers, engineers, chemists and other technicians, as well as for physicians and dentists, continues for any length of time.

The preceding paragraphs are not intended to present invidious comparisons, but to point up the fact that many "small" universities are no longer small, and that they may expect their constituencies to consider them capable of offering everything that the "large" schools offer. The dilemma is sharpened by the fact that libraries which were-possibly-capable of meeting adequately the demands of prewar days have not experienced a corresponding gain in either size or book budgets. The following table shows the relative positions of the two groups in these respects. book funds, the large only 5.2 per cent. This apparent gain should just about enable the first group to keep abreast of postwar cost levels; but it will not by any means permit a substantial broadening of acquisition activities into new fields in response to new demands. The larger libraries, of course, cannot at that rate maintain their purchasing at a prewar volume. But there are other factors to be considered here before this discrepancy is accepted at face value.

The first is the fact that the larger the library the less necessary it is to build basic book and periodical collections at currently inflated prices. Some of the very large collections no longer find it worth-while to devote more than a passing glance to the ordinary second-hand catalog, unless there is reason to believe that it conceals a treasure of some sort. Small collections facing heavy demands are very much in the market for basic periodicals and books which have not been acquired at the time

Table I

Volumes and Book Funds Per Student

\begin{tabular}{|c|c|c|c|c|}
\hline & \multicolumn{4}{|c|}{ Volumes } \\
\hline . & \multicolumn{2}{|c|}{ Seven Small Libraries } & \multicolumn{2}{|c|}{ Eight Large Libraries } \\
\hline $\begin{array}{l}\text { High } \\
\text { Low } \\
\text { Median }\end{array}$ & $\begin{array}{l}1939-40 \\
49 \cdot 7 \\
29 \\
36.5\end{array}$ & $\begin{array}{l}1946-47 \\
46.1 \\
22.1 \\
32\end{array}$ & $\begin{array}{c}1939-40 \\
116.5 \\
52.1 \\
71.95\end{array}$ & $\begin{array}{c}1946-47 \\
110.4 \\
44.3 \\
62.85\end{array}$ \\
\hline & \multicolumn{4}{|c|}{ Book Funds Per Student } \\
\hline & \multicolumn{2}{|c|}{ Seven Small Libraries } & \multicolumn{2}{|c|}{ Eight Large Libraries } \\
\hline $\begin{array}{l}\text { High } \\
\text { Low } \\
\text { Median }\end{array}$ & $\begin{array}{c}1939-40 \\
\$ 10.41 \\
3.22 \\
4.13\end{array}$ & $\begin{array}{c}1946-47 \\
\$ 11.02 \\
4.50 \\
6.39\end{array}$ & $\begin{array}{r}1939-40 \\
\$ 10.45 \\
5.34 \\
7.62\end{array}$ & $\begin{array}{r}1946-47 \\
\$ 12.99 \\
6.19 \\
\times \quad 8.02\end{array}$ \\
\hline
\end{tabular}

It will be observed that the percentage change in the median figure for volumes per student is very similar, being a little over 12 per cent for each group. The small libraries gained 54.7 per cent in median of publication because of lack of funds or lack of demand, or both. In short, the essential, classical foundations for a great many fields of study are already laid in the large library; they may be very sketchy or 
nonexistent in the small library.

A second factor is the gravitational force of great research collections in drawing the attention and the benefactions of donors, and the prestige value of adding something of special merit or interest to a great library. Harvard for years bought almost all its books from special endowment funds, not from university appropriations. Sometimes a large library may receive as gifts more volumes than it purchases. ${ }^{2}$ The publication of the Friends of the Library group of the University of North Carolina, for example, shows how valuable this source can be.

Exchanges are also of importance, and if the piece-for-piece rule is observed even approximately the large library is likely to have-more good material to send out than the small. ${ }^{3}$ This may include the publications of the university press, as at Cornell, a resource rarely available to the small school." Periodicals published by various units within the university also represent valuable exchange assets.

In three important respects, then, the large university library is more likely to have a definite advantage over the small one in acquisition matters. Its basic collections are more nearly adequate, it attracts more interest from donors who may have either money or books to give, and it has better resources for exchange negotiations because of the variety of material it receives from gifts, from the university press, or from a serial publication list of special distinction.

\section{Predetermined Decisions}

In addition to these concrete factors, there is another aspect of acquisition policy which deserves mention. This is the fact

${ }^{2}$ Columbia University Libraries. Report of the Director. . for the Academic Year Ending June 30 ,

${ }^{1947}$. New York, 1948 . "Two Years of Books by Barter." Harvard University Library Notes 4:29,

${ }^{1941 .}$ Cornell University Library. Report of the Direc. tor, $1946-47$. that great libraries to some extent enjoy, or perhaps suffer from, predetermined acquisition decisions which cannot be changed without great difficulty, if at all. These commitments result first of all from the existence of important research collections which have attracted scholars and students, and which have received much publicity at least in scholarly and research circles, and thus are a potent force in maintaining the fame of the library and the university. Taube cites several such commitments from various libraries which attempt to collect "all available material relating to Maine" or "everything printed in America before I 820 " or "everything relating to the literature and history, particularly local history, of Italy since 1870."

The Farmington Plan assignments illustrate very well the special interests of the great university libraries-as well as other research collections, of course-and it is extremely improbable that any of them would assume these heavy responsibilities without having pre-existing specialties in the subjects involved. While the building of an exhaustive research collection presents serious financial problems, it nevertheless does mean that the acquisition policy in that field is permanently determined and subject to no substantial changes. No special field in a great library can be de-emphasized without seriously depreciating all previous activity in it, antagonizing at least some of the faculty, and perhaps violating the legal and moral obligations attached to the acceptance of a gift which initiated the collection. The small library, if it has special interests, generally circumscribes them more closely geographically, chronologically, or in some other way, so that the resulting commitments are not too great to manage with the available funds. The pre-existing deci-

5 Taube, Mortimer. "The Theory of Book Selection." College and Research Libraries 2:222-23, December 1940. 
sion covers a small area of the large field, and general acquisition policy as it develops more or less independently of this permanent pre-existing policy must deal with the remainder.

A further point in this connection is the fact that some great libraries are so inclusive that the average trade book is very likely to have a strong presumption in its favor. An example has just come to hand in the State University of Iowa, which has placed standing orders for publications of most university presses and some commercial publishers. ${ }^{6}$ Such libraries could probably obtain every volume published by the university presses, Harper, Macmillan, and dozens of other well-known firms, as well as many minor ones, without serious qualms. This, again, requires great sums of money, but it does not involve the constant choice between books of apparently equal authority and value so characteristic of small library practice.

This willingness to accept books is not only a result of the wider subject coverage of the large library. In all probability it stems also from the fact that large universities and small ones often do not seem to treat parallel curricula in the same way. Courses of similar scope are developed more intensively and are likely to need a wider variety of reading, and to require more research and writing, in the former, perhaps because professors have an opportunity to examine most or all of the new books in a given field as they come to the library. What seems merely a good working collection in the great library may be regarded as a specialty in the small one because of this different approach to instruction.

The specializing tendency and the inclusive coverage of the large library thus

\footnotetext{
"Kilpatrick, Norman. "The University Library" in "The Technical Service Division in Libraries: a Symposium." College and Research Libraries 10:60, January 1949.
}

tend to create an almost automatic acquisition procedure for many books, periodicals and other items. While the essential nature of the process of book selection may be similar in the two types of libraries here contrasted, there are important factors which carry special weight in each. Our concern here is with those which affect the small collection, roughly, those lying below the median figure for state universities-about 300,000 volumes. Undoubtedly some of the things which apply to large libraries will also be true of certain small ones. On the other hand, some collections running well above the median figure may find themselves in a situation here attributed to those lying below it. No absolute general definition of a "small" or a "large" library is possible, since it depends upon the purposes and aims of the library and its parent institution. In dealing with generalities, the danger of exception is ever present. It is the writer's belief, based on experience in a very large research-library and in a small university collection, on discussion with other librarians, and on the examination of professional literature, that the points set out here, and the premises behind them, are substantially accurate.

If these views can be accepted, the conclusion follows that the formulation of an acquisition policy and of everyday criteria for selection requires a different approach in the small library than in the large. With both inadequate collections and inadequate funds it is especially important that the policy and procedure be based on the realities of a particular situation, and that every factor in the latter be considered with the utmost care. Only thus can the librarian fulfil his essential aim, which is to create through the most effective use of his resources the library best suited to the needs of the university as they are expressed in its formal program and in the individual requirements of students and faculty. 
Like all phenomena of human activity library growth is either accidental or planned, generally both. The chief accidental factors in the present case are the special interests of alumni or other donors who may give books or money for special uses; the requirements of scholars on the faculty with particular interests who demand, and often themselves supply, research materials for their own private studies and those of their students and co-workers; and the expressed needs and desires of teachers and students for literature to facilitate everyday teaching, the pursuit of hobbies, or recreational and avocational activities of one kind or another.

These accidental influences are very powerful factors in library development. It is probably true that their pressure increases as those who exert such influence attain positions of greater eminence in the outside world or carry more weight in university affairs. Great scholars can successfully demand more than the average instructor or assistant professor. All great universities and some small ones, as well as some colleges (e.g. Colby) have benefited greatly by the collecting work of their own faculty members or of other benefactors. For most small university libraries, however, the intrinsic values of these donations of money or books are not nearly so great as in the case of gifts made to larger ones. In fact, a special collection carrying appreciable financial obligations is not always welcome in any library; but the larger the collection, as a rule, the better it can undertake the financial obligations involved.

The accidental factor mentioned above, the everyday instructional and personal needs of faculty and students, is likely to be one of the most potent forces in acquisition policy generally, and of special force when both books and money are in short supply. The part it can properly play is worth extended consideration. In a library which does not intend to be a "trustee for the learned world" on any large scale the decision to purchase specific items is derived chiefly from the librarian's awareness of an active, felt need, or on his opinion regarding the future development of a need which as yet is potential. In other words, he buys what is needed or what is, in his own view, or in the opinion of men whose judgment he respects, likely to be needed in the predictable future.

The most accurate indices to actual existing needs are the expressed opinions of the faculty or the students. Where funds are low it may be considered that the filling of such demands is a first charge on book funds. The apportioning of money to schools, colleges, or departments for book purchases is a recognition of this view, although another important factor is the desire to place book selection largely in the hands of subject experts when the library is unable to employ them on its own budget. It is rare, however, for all book funds to be so allocated; in most schools some portion remains at the discretion of the librarian, and in spending it he can work to strengthen the collection along lines laid out in his own mind. Moreover, if he has the confidence of his faculty he is able to influence the expenditure of departmental funds to a considerable degree, so that his ideas have a greater weight than might at first be apparent.

To acquiesce in every suggested purchase from departmental funds, to comply with every demand for added money from general book funds until they are exhausted, and to buy everything possible which is expressly requested by students and faculty is the path of least resistance. It is, so to speak, the pragmatic approach to acquisition. Unfortunately it is not a safe course, for the demands made by teachers or student groups are not always proportionate either to their abilities or to their value in the university. Initiative, aggressiveness 
and pure gall are often the determinants which regulate their requests, rather than the real importance of their work or their interests. Those who ask most are not always the most deserving, nor is the filling of their needs necessarily the best investment for the good of the whole university.

The wise expenditure of general book funds and the exercise of the librarian's influence in directions which will produce the most profitable development of the library demand a more objective standard for judging proposed purchases. This standard, against which acquisition must be measured, can refer only to the program of the university in the most concrete and specific terms possible. Statements of philosophy, if we take the preamble appearing in many catalogs to be such, are generally of little value. Everyday decisions or longrange policy can hardly be formulated on the basis of education objectives like good citizenship, leadership, responsible adulthood, or sound scholarship. These are highly general attributes which higher education aims to develop and foster through the curriculum and the other activities of the university which are brought to bear on its students. Dr. C. H. Brown, in an article which should be reread especially by the librarians of small universities, expresses a view based on years of experience in a first-rate research library:

The library is a service institution. The needs of a library can be ascertained only by a study of the present and future needs of faculty and students, which in turn must be based, if a final analysis is to be made, on the needs of society or, in many cases, on the needs of a segment of society. All of us must give attention to the needs of the social groups which our particular college are to serve. $^{7}$

The commitments commonly existing in great research libraries were mentioned pre-

7 Brown, C. H. "Libraries and Graduate Programs, Especially in the Scientific Fields." College and Re. search Libraries 6:101, March 1945. viously. It must be recognized that the small university library also has responsibilities which cannot be abdicated. These are more likely to inhere in the character of the whole university than in the special character of the library; for a small library with scanty funds can hardly afford to build a character for itself other than as an instrument for the carrying on of a curricular program and the research investigation of subject fields closely tied in with the work of the school or the economic, social, political and historical interests of its own region or its own constituency. To put the matter in another way, the best use of severely limited resources must refer directly to either an institutional or a regional interest or program of work. It cannot with maximum profit be diverted to general or remote interests, except as they must be brought into the more specifically related program in order to orient the latter and to prevent the development or continuance of a provincialism and narrowness of viewpoint.

It is impossible here to study in detail the specific commitments which may or may not be justified in the small university. Generally speaking, the undergraduate program is of first importance, despite the almost universal feeling that a university is primarily a foundation for advanced research and professional training. Small universities usually offer very limited graduate programs; anyone wishing to pursue doctoral work lying outside the four or six or eight fields which may be offered must go elsewhere, and the local school's responsibility to these people ends at the baccalaureate, or possibly at the master's level. If, to these advanced students who must, go outside their own schools for further study, are added the vast majority who never go beyond the A.B. degree it can hardly be denied that their undergraduate preparation must be a first responsibility, no matter what the theory of university education may 
be. Nor can it be denied that to the residents and taxpayers of a state having a small university the undergraduate program is of overwhelmingly predominant interest. Following this are graduate and professional fields varying in local importance.

The small university has, besides its undergraduate program, a choice in developing its special interests. As a rule they develop, and should develop, along the lines of greatest pressure in the university, i.e., those determined by the interests and needs of its constituents, e.g., law, medicine, engineering, local history, etc. As a rule subjects having no close local ties are probably best left to the great research institutions which can afford to build libraries and hire teachers to handle them properly. Examples are medieval history, classical philology, general economic history and the like.

A perception of these forces and of these emphases is necessary to an intelligent acquisition policy, as well as a soundly based opinion on the precedence which should be accorded each component in the whole university program. It is often impossible or very difficult to obtain a statement from high administrative authority as to specific lines of development which are emerging, or are likely to emerge in the future, and there is some doubt that administrators, rather than the teaching faculty, should have a predominant voice in developing the curriculum. No professor will admit that he recognizes and accepts the fact that his specialty-say the history of Arctic exploration or the Arthurian legend-is unlikely to be much exploited in the library and that he is reconciled to doing his research elsewhere or by interlibrary loan, microfilm copy, or some other device for getting at the resources of good large li- braries. Yet a librarian can hardly spend severely limited funds wisely if he is unable to form conclusions regarding lines of development most likely to meet present and future demands, or if he is unaware of existing weaknesses.

The unfortunate fact is that parts of the average small university library must remain shallow in order that those subjects and those types of literature which are of special value to the specific program of the specific institution may be well developed. This is not to assert that such a situation, with its restriction on independent researches and its limiting effect on student and faculty interests is ideally desirable; it is merely an existing fact which must be recognized. The development of a new subject field at the expense of either the resources of undergraduate education or the materials needed for the study of subjects already forming important parts of a university program is not likely to be profitable to the institution as a whole, whatever it may mean to the individual librarian or faculty member. Dr. Brown has this to say regarding the necessity of limiting the aspirations of a library:

A requirement for an adequate library for graduate study which must have first consideration is a clear-cut definition of the fields which are to be covered by the college. Universities have an unusual opportunity to develop intensively certain fields both in pure and applied science and in the humanities. By limiting their fields, they can become outstanding in certain areas. No library now can be all things to all people. There is some possibility that in a given case we can build up an adequate library for research in a limited number of fields. If we make the mistake of adding to these definite fields all the areas of human knowledge, we shall be lost. $^{8}$

\footnotetext{
s Ibid., p. 102.
} 